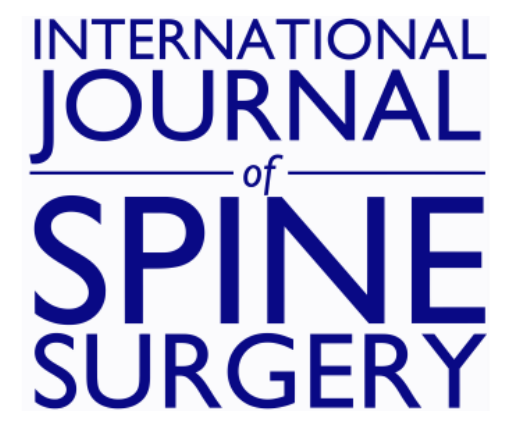

\title{
Preliminary Results of Bioactive Amniotic Suspension with Allograft for Achieving One and Two-Level Lumbar Interbody Fusion
}

Pierce D. Nunley, Eubulus J. Kerr III, Philip A. Utter, David A. Cavanaugh, Kelly A. Frank, Devan Moody, Brian McManus and Marcus B. Stone

Int J Spine Surg 2016, 10 ()

doi: https://doi.org/10.14444/3012

http://ijssurgery.com/content/10/12

This information is current as of April 25, 2023.

Email Alerts Receive free email-alerts when new articles cite this article. Sign up at:

http://ijssurgery.com/alerts

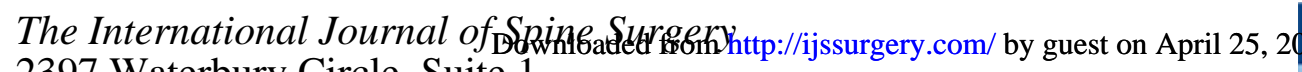
2397 Waterbury Circle, Suite 1,

Aurora, IL 60504, Phone: +1-630-375-1432 


\section{Preliminary Results of Bioactive Amniotic Suspension with Allograft for Achieving One and Two-Level Lumbar Interbody Fusion}

Pierce D. Nunley, MD, Eubulus J. Kerr III, MD, Philip A. Utter, MD, David A. Cavanaugh, MD, Kelly A. Frank, MS, Devan Moody, Brian McManus, Marcus B. Stone, $P h D$

Spine Institute of Louisiana, Shreveport, Louisiana, USA

\section{Abstract}

Background

Bone graft material for lumbar fusion was historically autologous bone graft (ABG). In recent years alternatives such as allograft, demineralized bone matrix (DBM), ceramics, and bone morphogenetic protein (BMP) have gained favor, although the complications of these are not fully understood. Bioactive amniotic suspension (BAS) with allograft is a new class of material derived from human amniotic tissue.

Methods

Eligible patients receiving a one or two level lumbar interbody fusion with Nucel, a BAS with allograft, were contacted and scheduled for a mininmim 12 month follow-up visit. Patients were evaluated for fusion using CT's and plain radiographs. Clincal outcomes, including ODI, VAS back and leg were collected, as well as comorbidities including BMI, smoking status, diabetes and previous lumbar surgery.

Results

One-level patients $(\mathrm{N}=38)$ were $71.1 \%$ female with mean age of $58.4 \pm 12.7$ and mean BMI of $30.6 \pm 6.08$. Two-level patients ( $\mathrm{N}=34)$ were $58.8 \%$ female with mean age of $49.3 \pm 10.9$ and mean BMI of 30.1 \pm 5.82 . Kinematic fusion was achieved in $97.4 \%$ of one-level patients and $100 \%$ of two-level patients. Baseline comorbidities were present in $89.5 \%$ of one-level patients and $88.2 \%$ of two-level patients. No adverse events related to BAS were reported in this study.

\section{Conclusion}

Fusion status is evaluated with many different biologics and varying methods in the literature. BAS with allograft in this study demonstrated high fusion rates with no complications within a largely comorbid population. Although a small population, BAS with allograft results were encouraging for one and two-level lumbar interbody fusion in this study. Further prospective studies should be conducted to investigate safety and efficacy in a larger population.

KEYWORDS: LUMBAR FUSION, BONE GRAFT, BIOACTIVE AMNIOTIC SUSPENSION, ALLOGRAFT, BONE GRAFT ALTERNATIVE, NUCEL

VOLUME 10 ARTICLE 12 DOI: 10.14444/3012

\section{Introduction}

Autologous bone graft (ABG) is still considered by many as the gold standard of graft material for spinal fusion, as it comprises all of the properties of an ideal graft: osteoinduction, osteoconduction, and osteogenesis. In addition, ABG for grafting purposes offers complete histocompatibility and has shown excellent fusion rates. ${ }^{1}$ However, the use of ABG in spinal fusion has progressively declined in recent years due to the well-documented complications associated with harvesting of the graft itself. ${ }^{2,3}$ Other shortcomings of $A B G$ include variability in graft quality and limited availability. These issues have prompted the search for alternatives of bone grafting materials that are equally as effective as $\mathrm{ABG}$ in achieving arthrodesis.

Alternatives to ABG include various forms of allograft, demineralized bone matrix (DBM), ceramics, and bone morphogenetic protein (BMP). Many of these options meet results shown by the gold standard, but lack long term data; specifically complicaDownloaded from http://ijssurgery.com/ by guest on April 25, 2023 
tions are not fully understood. ${ }^{4} \mathrm{BMP}$ possesses potent osteoinductive properties and has produced superior results to iliac crest bone graft in fusion procedures. ${ }^{5,6}$ However, many adverse events have been reported ${ }^{7-9}$ since the FDA's approval of BMP for lumbar interbody fusion in 2002 .

NuCel@ belongs to a new class of bioactive amniotic suspension (BAS) material derived from human amniotic tissue. $\mathrm{NuCel}$ has historically been used in spine and orthopedic applications; however there is significant interest and on-going research in wound healing. The allograft tissues, consisting of amniotic membrane and cells from the amniotic fluid and the amniotic membrane, are collected during elective cesarean sections.All donors are properly consented before tissue donation and are screened according to FDA and AATB standards. Standard production cryopreservation techniques, including controlledrate freezing, are used to preserve native cell viability. $\mathrm{NuCel}$ has been on the market since 2009 , with over 25,000 doses implanted to date. In that time there have been no reported complaints related to immune reactions or other safety issues. In a different orthopedic application, specifically treatment of knee osteoarthritis, ${ }^{10}$ testing of the immune response was evaluated by evaluating C-reactive protein, erythrocyte sedimentation rate, $\mathrm{T}$ cells, $\mathrm{B}$ cells, and natural killer cells. Additionally, serum was assayed for $\operatorname{IgG}, \operatorname{Ig} A, \operatorname{IgM}$ and $\operatorname{IgE}$ over the course of 1 year. These data showed that there was no significant immune response caused by the product.

For BAS use in spinal fusion, human amniotic fluid has shown to be a source of mesenchymal stem cells that are known to be pluripotent, capable of differentiating into many cellular phenotypes, including osteocytes. ${ }^{11-13}$ Several studies have shown successful outcomes in the application of amniotic fluid in softtissue wound healing ${ }^{14}$ and in several orthopedic conditions, including cartilage, ligament, and bone ${ }^{15,16}$ repair. BAS can be used as an adjunct to allograft bone substitute to promote arthrodesis in spinal fusion procedures. To the best of our knowledge there have been no studies previously performed to analyze the use of BAS in the spine. The goal of this study is to report the preliminary results of a novel BAS product derived from amniotic fluid in patients receiving lumbar interbody fusions.

\section{Methods}

One-hundred retrospectively identified subjects met the inclusion/exclusion criteria for this IRB approved study. Each subject must have been treated with BAS (NuCel, Nutech Medical, Birmingham, AL) during the course of a one or two-level lumbar interbody fusion between L1-S1. The surgical approach and interbody cage implanted were at the discretion of the surgeon. Minimally invasive posterior fixation was utilized on all patients with percutaneous pedicle screws, no posterior fusion was performed. The indications for surgery for patients were most commonly spondylolisthesis, spondylosis, radiculopathy and DDD. There were a small number of patients that had a herniated nucleus pulpous. All patients were treated at a single center with surgeries being performed by two fellowship trained spine surgeons. In addition, patients prospectively must have been willing and able to undergo a CT scan and xrays and able to complete patient centered outcome questionnaires. Subjects were excluded from the study if they: were pregnant, had been experiencing back pain due to acute trauma; had evidence of back pain secondary to any infectious agents, metabolic bone diseases, or malignancy; had any autoimmune disease history; had any recent history of chemical or alcohol dependence; or if they were currently experiencing any major mental illness.

Retrospectively identified patients eligible for the study were contacted via telephone and were scheduled for a one-time prospective follow-up appointment. Informed consent was obtained from the patient at the follow-up visit, before any study specific procedures were performed. During the visit, subjects completed two questionnaires and received a $\mathrm{CT}$ scan and plain radiographs of the lumbar spine.

Clinical outcomes were based on neurologic status and two different patient centered outcome questionnaires, including: visual analog pain scale (VAS) and Oswestry Disability Index (ODI).The VAS determined the amount of pain experienced in each of: the lower back, right lower extremity, and left lower extremity. The VAS and ODI scores obtained during 
the follow-up visit were compared to scores that were obtained from the subject pre-operatively

Plain radiographs of the lumbar spine in anteroposterior view, lateral bending view, as well as lateral views in flexion and extension positions and non-contrast computerized tomography (CT) scans of the lumbar spine were captured at the follow-up visit. CT was preformed using a Siemens Somatom Emotion 16 with $0.6 \mathrm{~mm}$ slice width. The $\mathrm{CT}$ scans and $\mathrm{X}$-rays were assessed for fusion by an independent radiologist. Fusion was scored according to the alphanumeric scale as described in Figure 1.

Surgeons commonly assess fusion as a combination of bridging bone and lack of motion at the index level..$^{17-19}$ Therefore, lateral flexion-extension radiographs were also evaluated for evidence of motion greater than five degrees at the operative level. Kinematic fusion was defined as a combined measure of $\mathrm{CT}$ fusion classification of $2 \mathrm{~A}$ or $3 \mathrm{~A}$, with radiographic confirmation of less than five degrees of motion on the flexion-extension films. ${ }^{19,20}$

Patient medical history was reviewed for demographic information and the presence of comorbidities including; smoking, diabetes, previous lumbar spine surgery (PLS), and Body Mass Index (BMI) categorized according to $\mathrm{NIH}$ standards as overweight $(\geq 25$ and $<30)$, or obese $(\geq 30)$.

\section{Results}

Fifty-eight one-level patients and 42 two-level patients met inclusion/exclusion criteria, with 38 (onelevel) and 34 (two-level) patients that consented to

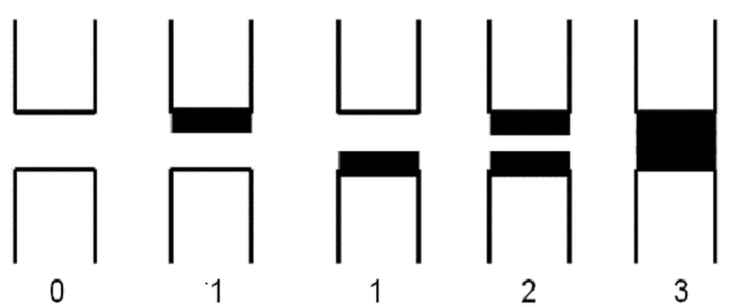

Fig. 1. CT Classification of Spinal Fusion. 0 - No bony ingrowth; 1 Cranial downgrowth or caudal upgrowth; 2 - Cranial downgrowth and caudal upgrowth but NOT bridging; 3 - Complete bridging trabecular bone fusion; A - No evidence of supplemental fixation failure/no halo seen; B Evidence of supplemental fixation failure/halo seen. participate in the study. The prospective follow-up visit was a minimum of 12 months post-operation with average of 27.3 months for one-level patients and 28.2 months for two-level patients. Seventeen one-level patients and 18 two-level patients reached 24 months follow-up. Demographics for the one and two-level patients are included as Table 1.

The levels treated from L1-S1 are stratified in Table 2 and Table 3, the most treated level was L4-L5 for one-level and L4-S1 for two-level patients.

Surgical approach was left to the discretion of the surgeon. Of the 38 one-level patients, ALIF (14) and LLIF (15) were the most common surgical approaches with TLIF (9) being utilized for the remaining patients. The two-level approach most commonly used was ALIF (25), with the remaining patients receiving LLIF (7) and TLIF (1). One two-level patient re-

Table 1. Patient Demographics.
\begin{tabular}{|l|r|r|}
\hline Demographic & One-Level & Two-Level \\
\hline N (No.) & 38 & 34 \\
\hline Age (Mean \pm SD) & $58.4 \pm 12.7$ & $49.3 \pm 10.9$ \\
\hline BMI (Mean \pm SD) & $30.6 \pm 6.08$ & $30.1 \pm 5.82$ \\
\hline Male (\%) & $11(28.9)$ & $14(41.2)$ \\
\hline Female (\%) & $27(71.1)$ & $20(58.8)$ \\
\hline
\end{tabular}

Table 2. Levels treated in one-level patients.

\begin{tabular}{|l|r|}
\hline \multicolumn{2}{|l|}{ One-Level } \\
\hline Levels Treated & No. Patients \\
\hline L1-L2 & 1 \\
\hline L2-L3 & 1 \\
\hline L3-L4 & 6 \\
\hline L4-L5 & 20 \\
\hline L5-S1 & 10 \\
\hline
\end{tabular}

Table 3. Levels treated in two-level patients.

\begin{tabular}{|l|r|}
\hline \multicolumn{2}{|l|}{ Two-Level } \\
\hline Levels Treated & No. Patients \\
\hline L2-L4 & 1 \\
\hline L3-L5 & 9 \\
\hline L4-S1 & 24 \\
\hline
\end{tabular}


ceived a combined approach of TLIF and LLIF.

\section{Fusion Status}

Fusion status was available and graded for all enrolled patients. Representative examples of a $2 \mathrm{~A}$ and $3 \mathrm{~A}$ fusion status are included as Figure 2 and Figure 3.

The patient results of the CT fusion classification and radiographic fusion success are included in Figure 4 and Figure 5.

For two-level patients fusion status was further stratified by levels with Figure 6 reporting fusion status

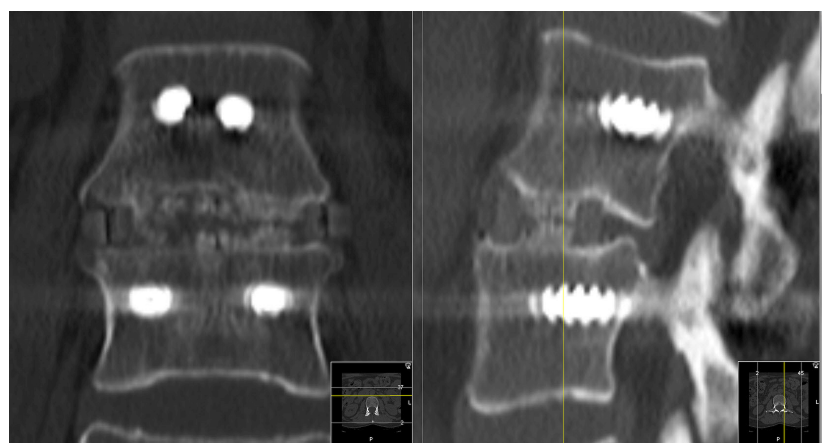

Fig. 2. Representative example of $2 \mathrm{~A}$ fusion status

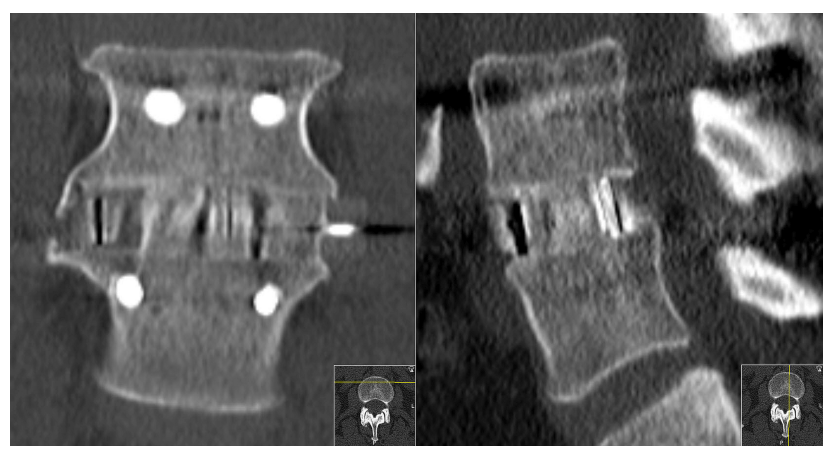

Fig. 3. Representative example of 3A fusion status.

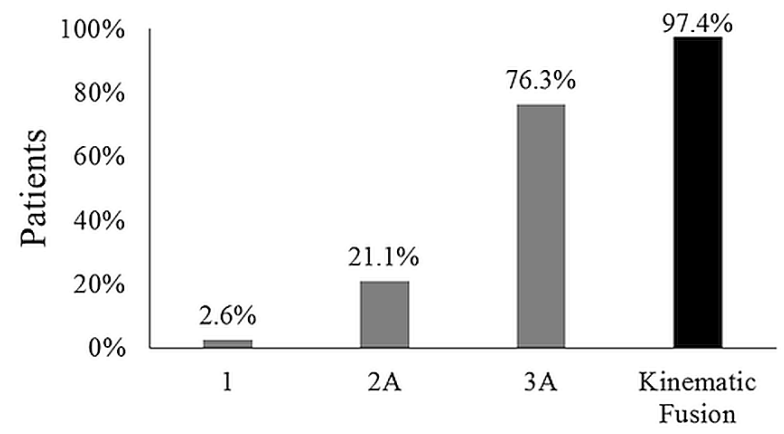

Fig. 4. One-level fusion status. out of 68 total treated levels.

Applying the definition of kinematic fusion (minimum 2A status and flexion/extension confirmation < 5 degrees motion in the segment), $97.4 \%$ of one-level patients and $100 \%$ of two-level patients were clinically fused. When combining the one and two-level patients the total fusion rate by levels was $99.1 \%$. The single one-level patient that was not clinically fused, received a CT fusion status of 1 and had motion at the index level. The CT status did not have an alpha grade, because the patient had posterior hardware removed in a subsequent surgery. The patient experienced right side low back pain that began 6 months post-operatively and persisted. After undergoing multiple injections to the hardware site that improved the pain, the patient underwent a hardware removal 18 months post-operatively. Seven months after removal of the hardware, the patient reported a score of zero for VAS back pain.

The CT fusion rate was analyzed in conjuction with surgical approach. The stratification of the data into smaller groups by surgical approach limited the ability to perform any realible statistical tests, so the raw data is presented in Table 4.

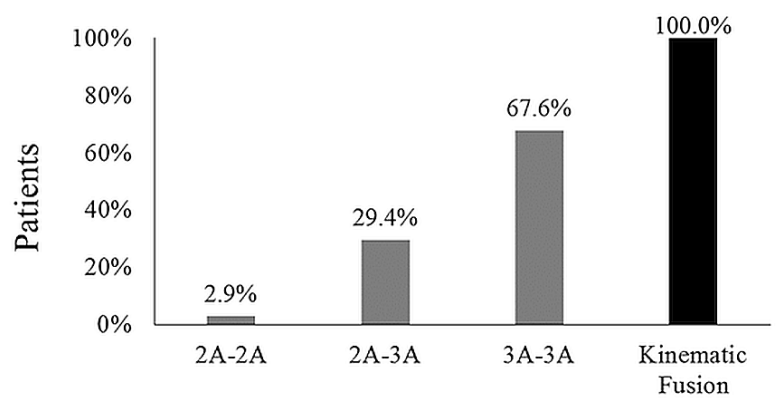

Fig. 5. Two-level fusion status by patient.

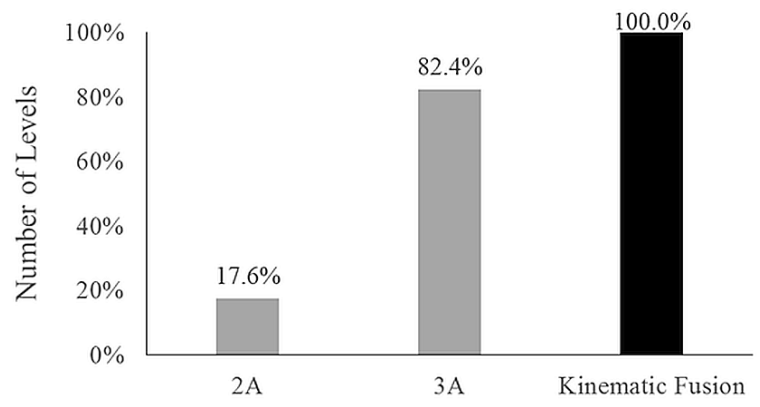

Fig. 6. Two-level fusion status by level. 
Comorbidities

In the one-level patient population, $89.5 \%$ of patients had at least one comorbidity and $65.8 \%$ had two or more. At least one comorbidity was present in $88.2 \%$ of two-level patients with $29.4 \%$ having two or more.

Comorbidities for both the one and two-level patient population are further stratified in Table 5 .

The one and two-level population included only $10.5 \%$ and $11.8 \%$ respectively of patients without a comorbidity. Fifty percent of all patients were obese at the time of surgery, with $39.5 \%$ of the one-level patients being obese in combination with another comorbidity. Smoking patients were $28.9 \%$ of the onelevel population and $23.5 \%$ of two-level population. All smoking patients in the one-level population had at least one other comorbidity, while $14.7 \%$ of the two-level patients had another comorbidity in addition to smoking. Diabetes, as expected, was present in the overweight and obese populations, with $26.3 \%$ of one-level and $11.8 \%$ of two-level patients having diabetes.

\section{Outcomes}

All patients answered a VAS back/leg questionnaire and ODI at the post-operative visit, although not every patient had a pre-operative value. Figure 7 and Figure 8 below include all available patients with preoperative and post-operative outcomes.

Patients reported average VAS back improvement of 22.2 (one-level) and 27.0 (two-level. VAS leg improvement for right and left legs respectively was 15.9 and 8.0 for one-level and 14.0 and 19.1 for twolevel. One-level patients' ODI scores improved on average 18.5 points and two-level scores improved 14.7 points.

Table 4. Fusion Status by Surgical Approach.
\begin{tabular}{|l|r|r|r|r|}
\hline & \multicolumn{3}{|l|}{ CT Fusion Status } \\
\hline Approach & $\mathbf{1}$ & $\mathbf{2 A}$ & $\mathbf{3 A}$ & Total Levels \\
\hline ALIF & 0 & 11 & 53 & 64 \\
\hline LLIF & 0 & 7 & 23 & 30 \\
\hline TLIF & 1 & 2 & 9 & 12 \\
\hline
\end{tabular}

\begin{tabular}{|c|c|c|c|}
\hline $\begin{array}{l}\text { No. of } \\
\text { Comorbidities }\end{array}$ & Comorbidities & One-Level & Two-Level \\
\hline None & $\mathrm{N} / \mathrm{A}$ & $4(10.5 \%)$ & $4(11.8 \%)$ \\
\hline \multicolumn{2}{|c|}{ Total of Patients with No Comorbidities } & $4(10.5 \%)$ & $4(11.8 \%)$ \\
\hline \multirow{4}{*}{ One } & Overweight & $3(7.9 \%)$ & $6(17.6 \%)$ \\
\hline & Obese & $4(10.5 \%)$ & $11(32.4 \%)$ \\
\hline & PLS & $2(5.3 \%)$ & $0(0.0 \%)$ \\
\hline & Smoking & $0(0.0 \%)$ & $3(8.8 \%)$ \\
\hline \multicolumn{2}{|c|}{ Total of Patients with One-Comorbidity } & $9(23.7 \%)$ & $\begin{array}{l}20 \\
(58.8 \%)\end{array}$ \\
\hline \multirow{6}{*}{ Two } & Smoking / PLS & $1(2.6 \%)$ & $0(0.0 \%)$ \\
\hline & Overweight / PLS & $5(13.2 \%)$ & $1(2.9 \%)$ \\
\hline & Overweight / Smoking & $1(2.6 \%)$ & $2(5.9 \%)$ \\
\hline & Overweight / Diabetes & $1(2.6 \%)$ & $1(2.9 \%)$ \\
\hline & Obese / Smoking & $5(13.2 \%)$ & $2(5.9 \%)$ \\
\hline & Obese / Diabetes & $3(7.9 \%)$ & $2(5.9 \%)$ \\
\hline \multicolumn{2}{|c|}{ Total of Patients with Two-Comorbidities } & $\begin{array}{l}16 \\
(42.1 \%)\end{array}$ & $8(23.5 \%)$ \\
\hline \multirow{5}{*}{ Three } & $\begin{array}{l}\text { Overweight / Smoking / } \\
\text { PLS }\end{array}$ & $1(2.6 \%)$ & $0(0.0 \%)$ \\
\hline & $\begin{array}{l}\text { Overweight / Diabetes / } \\
\text { PLS }\end{array}$ & $1(2.6 \%)$ & $0(0.0 \%)$ \\
\hline & $\begin{array}{l}\text { Obese / Smoking / } \\
\text { Diabetes }\end{array}$ & $1(2.6 \%)$ & $0(0.0 \%)$ \\
\hline & Obese / Diabetes / PLS & $4(10.5 \%)$ & $1(2.9 \%)$ \\
\hline & Obese / Smoking / PLS & $2(5.3 \%)$ & $1(2.9 \%)$ \\
\hline \multicolumn{2}{|c|}{ Total of Patients with Three Comorbidities } & $9(23.7 \%)$ & $2(5.9 \%)$ \\
\hline
\end{tabular}

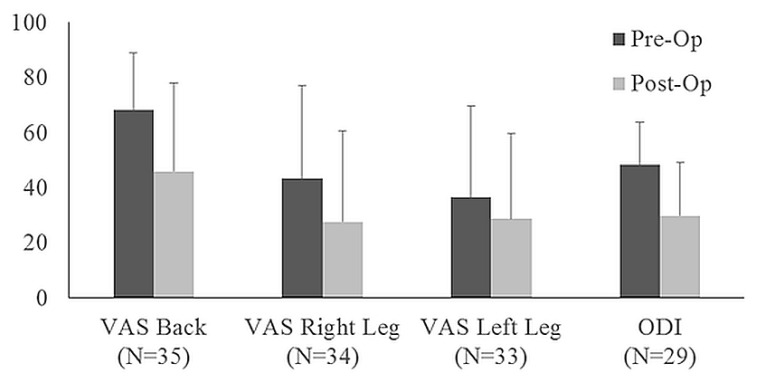

Fig. 7. One-Level Clinical Outcomes preoperative and postoperative. Error Bars show standard deviation from the mean. 


\section{Discussion}

The nature of this study incorporated a largely comorbid patient population, with $89.5 \%$ of one-level patients and $88.2 \%$ of two-level patients having at least one comorbidity. It has been reported that multilevel surgery, and patients with comorbidities, such as rheumatoid arthritis and smoking have a higher risk of reduced fusion. ${ }^{21-25}$ In this study $97.4 \%$ of onelevel patients and $100 \%$ of two-level patients achieved a kinematic fusion. In Andersen, et al. the fusion rate (determined by radiographic bridging trabecular bone) for pre-operative smokers was $84.8 \%$ compared to $91.1 \%$ for non- smokers. The fusion rate reduced to $81.8 \%$ if the patient was smoking more than 10 cigarettes daily. Anayzing patients that smoked postoperatively the fusion rate was reduced to $77.8 \%$, regardless of their smoking status pre-operatively. The authors used predictive statistics, and determined that smoking more than 10 cigarettes a day preoperatively doubled the risk of a non-union. ${ }^{24}$ In this study, $28.9 \%$ of one-level and $23.5 \%$ of two-level patients smoked, but $100 \%$ of smoking patients achieved kinematic fusion. In prospective studies, the exclusion criteria typically do not allow high risk comorbidities. In Malham, et al. only $9.2 \%$ of patients smoked, and morbid obesity was an exclusion while our study included $50.0 \%$ of one-level patients and two-level patients that met the NIH definition of obese $(\mathrm{BMI} \geq 30){ }^{26}$

\section{Fusion Rate}

Review of literature indicates that ALIF with ABG has long been the gold standard of treatment for symptomatic degenerative lumbar disc disease. ${ }^{21,27,28}$ However alternatives, such as allograft and multiple

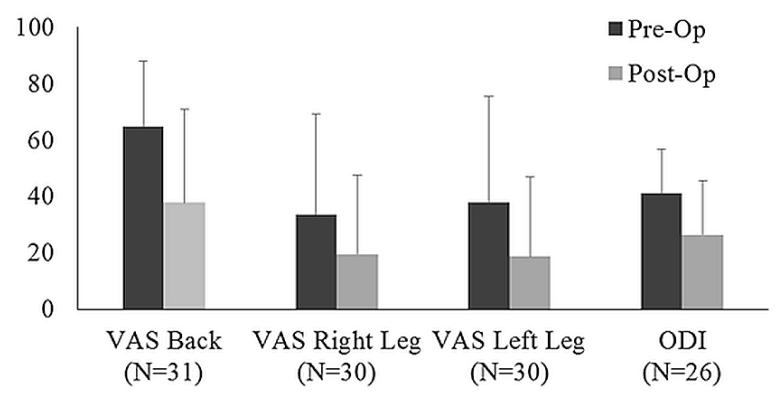

Fig. 8. Two-Level Clinical Outcomes preoperative and postoperative. Error Bars show standard deviation from the mean. synthetic materials, have recently gained favor due to the complications of harvesting ABG (increased donor site morbidity, blood loss and operation time)..$^{27,29,30}$

In the current study, 38 one-level patients and 34 two-level patients received interbody fusion with allograft and BAS. One-level patients had a kinematic fusion rate of $97.4 \%$. One patient in the one-level population did not achieve clinical, fusion after she experienced painful hardware and required a subsequent surgery to remove the posterior screws and rods. Although multilevel fusion is published as a risk for non-union, ${ }^{24,25} 100 \%$ of the two-level patients achieved kinematic fusion. The combined one and two-level kinematic fusion rate by number of levels treated was $99.1 \%$.

A specific paper of interest, Santos et al., compared fusion rates using five different methods of evaluation after surgical fusion using autologous bone. Four methods used plain radiographs for evaluation, while the last used CT. The fusion rates using plain radiograph evaluation ranged from $74 \%$ to $96 \%$, while the fusion rate with CT was $65 \% .{ }^{31}$ The CT method of fusion evaluation is a more stringent criteria than plain radiographs, regardless of the bone graft material utilized. The study presented here used CT evaluation of fusion with a $3 \mathrm{~A}$ status showing full fusion. The levels reaching a $3 \mathrm{~A}$ fusion were $76.3 \%$ of onelevel surgeries and $82.4 \%$ of two-level surgeries, indicating evaluation by plain radiographs could show a higher fusion rate.

Rates of fusion in the literature vary depending on graft material and the method used to evaluate fusion. Table 6 is a review of the recent literature of fusion rates using various graft material and fusion analysis method. Overall, rhBMP-2 has reported fusion rates from $83 \%$ to $98 \%{ }^{26,32,33}$ The lower end of the fusion rate occurred when rhBMP-2 was combined with ICBG or LBG, while the highest fusion rate was seen in a prospective study using only rhBMP-2 in the cage. B2A peptide shows strong fusion rates at $100 \%$, when utilized in the larger studied dosage. ${ }^{19} \mathrm{At}$ 12 months, ABG has the lowest fusion rates between $73 \%-82 \%$, as reported across multiple studies. ${ }^{19,34,35}$ Silicate-substituted calcium phosphate lumbar fusion 
rates using CT were reported as $76.2 \%$ and $80 \%$ in two separate reported studies. ${ }^{36,37}$ The NuCel fusion rate of $99.1 \%$ for all treated levels is a comparative fu- sion rate with other published results of synthetic bone grafts in lumbar fusion. 
Table 6. Published Fusion Rates for Bone Grafts.

\begin{tabular}{|c|c|c|c|c|c|}
\hline Author & Evaluation of Fusion & Graft Material & Comorbidities & Time & Fusion Rate \\
\hline \multirow{2}{*}{$\begin{array}{l}\text { Dimar et al. } \\
(2006)^{32}\end{array}$} & \multirow[b]{2}{*}{ CT : Solid Unilateral or bilateral fusion } & rhBMP-2/CRM & $\begin{array}{l}\text { Workers comp - } 13.2 \% \\
\text { Spinal litigation- } 3.8 \% \\
\text { Smoking- } 32.1 \%\end{array}$ & $\begin{array}{l}12 \\
\text { months }\end{array}$ & $90.6 \%$ \\
\hline & & ICBG & $\begin{array}{l}\text { Workers comp - } 17.8 \% \\
\text { Spinal litigation - } \\
15.6 \% \\
\text { Smoking - } 22.2 \%\end{array}$ & $\begin{array}{l}12 \\
\text { months }\end{array}$ & $73.3 \%$ \\
\hline $\begin{array}{l}\text { Jenis and } \\
\text { Banco } \\
(2010)^{37}\end{array}$ & CT: Graft consolidation on a least 2 contiguous cuts and in at least 2 of 3 planes & Silicate-substituted calcium phosphate (Actifuse, Baxter) & $\begin{array}{l}\text { Smoking- } 9.5 \% \\
\text { Diabetics- } 9.5 \%\end{array}$ & $\begin{array}{l}12 \\
\text { months }\end{array}$ & $76.2 \%$ \\
\hline $\begin{array}{l}\text { Nagineni et } \\
\text { al. }(2012)^{36}\end{array}$ & CT: Graft consolidation on a least 2 contiguous cuts and in at least 2 of 3 planes & Silicate-substituted calcium phosphate (Actifuse, Baxter) & Smoking $-11 \%$ & $\begin{array}{l}\sim 12 \\
\text { months }\end{array}$ & $\begin{array}{l}80 \% \\
\text { (Lumbar } \\
\text { only) }\end{array}$ \\
\hline \multirow{2}{*}{$\begin{array}{l}\text { Nandyala et } \\
\text { al. }(2014)^{38}\end{array}$} & \multirow{2}{*}{$\begin{array}{l}\text { CT: Presence of bridging trabecular bone on at least } 2 \text { consecutive coronal and } \\
\text { sagittal images, blurring of the bone-graft endplate junction, and absence of } \\
\text { radiologic cleft within fusion mass }\end{array}$} & A Silicate-substituted calcium phosphate (Actifuse, Baxter) & $\begin{array}{l}\text { Workers comp - } \\
38.5 \% \\
\text { Smoking }-30.8 \%\end{array}$ & $\begin{array}{l}12 \\
\text { months }\end{array}$ & $65.4 \%$ \\
\hline & & rhBMP-2 (INFUSE, Medtronic, Inc.) & $\begin{array}{l}\text { Workers comp - } \\
26.9 \% \\
\text { Smoking }-26.9 \%\end{array}$ & $\begin{array}{l}12 \\
\text { months }\end{array}$ & $92.3 \%$ \\
\hline \multirow{2}{*}{$\begin{array}{l}\text { Roh et al. } \\
(2013)^{39}\end{array}$} & \multirow{2}{*}{$\begin{array}{l}\text { Radiograph: Presence of bridging bone across endplates or from endplates to } \\
\text { interspace disc plugs }\end{array}$} & rhBMP-2 (INFUSE, Medtronic, Inc.) & Not available & $\begin{array}{l}12 \\
\text { months }\end{array}$ & $83.5 \%$ \\
\hline & & Allogenic Morphogenic protein (OsteoAMP, Advanced Biologics) & Not available & $\begin{array}{l}12 \\
\text { months }\end{array}$ & $93.3 \%$ \\
\hline \multirow{2}{*}{$\begin{array}{l}\text { Park et al } \\
(2013)^{33}\end{array}$} & \multirow{2}{*}{$\begin{array}{l}\text { CT: Presence of bridging trabecular bone on at least } 2 \text { images and cortication of } \\
\text { the peripheral edges of the fusion mass }\end{array}$} & rhBMP-2 (INFUSE, Medtronic) with LBG & Not available & $\begin{array}{l}12 \\
\text { months }\end{array}$ & $85.7 \%$ \\
\hline & & rhBMP-2 (INFUSE, Medtronic) with ICBG & Not available & $\begin{array}{l}12 \\
\text { months }\end{array}$ & $83.4 \%$ \\
\hline $\begin{array}{l}\text { Malham, et } \\
\text { al. }(2014)^{26}\end{array}$ & $\mathrm{CT}$ : Presence of bridging trabecular bone & rhBMP-2 (INFUSE, Medtronic, Inc.) & $\begin{array}{l}\text { Smoking-9.2\% } \\
\text { Diabetes-2.3\% } \\
\text { Hypertension-7.6\% } \\
\text { Depression-3.8\% } \\
\text { Prior lumbar } \\
\text { surgery-14.5\% }\end{array}$ & $\begin{array}{l}12 \\
\text { months }\end{array}$ & $\begin{array}{l}\text { 96.5\% ALIF } \\
97.8 \text { Hybrid }\end{array}$ \\
\hline $\begin{array}{l}\text { Ammerman, } \\
\text { et al. } \\
(2013)^{17}\end{array}$ & $\begin{array}{l}\text { If patient asymptomatic: Radiographic evidence of bridging bone with no motion } \\
-100 \% \text { of patients evaluated with radiograph } \\
\text { or } \\
\text { If patient symptomatic : } \mathrm{CT} \text { evidence of bridging bone }\end{array}$ & $\begin{array}{l}\text { Allograft cellular bone matrix containing mesenchymal stem cells (MSCs) and osteoprogenitor } \\
\text { cells combined with DBM and cancellous bone (Osteocel Plus, Nuvasive) }\end{array}$ & $\begin{array}{l}\text { Osteoporosis - } 4.3 \% \\
\text { Diabetes - } 13.0 \% \\
\text { Smoking - } 4.3 \% \\
\text { Chronic steroid use - } \\
4.3 \%\end{array}$ & $\begin{array}{l}12 \\
\text { months }\end{array}$ & $92.3 \%$ \\
\hline $\begin{array}{l}\text { Tohmeh et } \\
\text { al. }(2012)^{40}\end{array}$ & $\begin{array}{l}\text { Fluoroscopy-guided radiography (FGX)- } 98 \% \text { of patients evaluated with FGX } \\
\text { or } \\
\text { CT: Complete ossification with some component of endplate involvement. - One } \\
\text { patient (3\%) was evaluated with CT }\end{array}$ & $\begin{array}{l}\text { Allograft cellular bone matrix containing mesenchymal stem cells (MSCs) and osteoprogenitor } \\
\text { cells combined with DBM and cancellous bone (Osteocel Plus, Nuvasive) }\end{array}$ & $\begin{array}{l}\text { Tobacco use - } 12.5 \% \\
\text { Coronary Artery } \\
\text { Disease - } 47.5 \% \\
\text { Diabetes - } 20 \% \\
\text { COPD - } 5 \% \\
\text { Steroid use - } 8 \% \\
\text { Any prior spine } \\
\text { surgery - } 65 \%\end{array}$ & $\begin{array}{l}12 \\
\text { months }\end{array}$ & $90.20 \%$ \\
\hline \multirow{3}{*}{$\begin{array}{l}\text { Sardar, et } \\
\text { al. }(2015)^{19}\end{array}$} & \multirow{3}{*}{$\begin{array}{l}\text { Based on Medical Metrics Inc. (Houston, Texas) criteria using CT and } \\
\text { radiographs: } \\
\text { Evidence of bridging bone } \\
\text { Less than } 50 \% \text { radiolucency } \\
\text { Less than } 5 \text { degrees of motion and less than } 3 \mathrm{~mm} \text { translation }\end{array}$} & B2A peptide (Prefix 150, BioSET, Inc) & Not available & $\begin{array}{l}12 \\
\text { months }\end{array}$ & $50 \%$ \\
\hline & & B2A peptide (Prefix 750, BioSET, Inc) & Not available & $\begin{array}{l}12 \\
\text { months }\end{array}$ & $100 \%$ \\
\hline & & ICBG & Not available & $\begin{array}{l}12 \\
\text { months }\end{array}$ & $77.80 \%$ \\
\hline
\end{tabular}

Downloaded from http://ijssurgery.com/ by guest on April 25, 2023 


\begin{tabular}{|c|c|c|c|c|c|}
\hline Author & Evaluation of Fusion & Graft Material & Comorbidities & Time & Fusion Rate \\
\hline \multirow{2}{*}{$\begin{array}{l}\text { Lauweryns, } \\
\text { et al. } \\
(2015)^{34}\end{array}$} & \multirow{2}{*}{ CT : Presence of bridging trabecular bone } & ABM/P-15 (i-FACTOR, Cerpedics, Inc.)* & \multirow{2}{*}{$\begin{array}{l}\text { BMI } 25-30-40 \% \\
\text { BMI }>30-20 \% \\
\text { Tobacco use }-27.5 \% \\
\text { Diabetes }-12.5 \%\end{array}$} & $\begin{array}{l}12 \\
\text { months }\end{array}$ & $97.78 \%$ \\
\hline & & $\mathrm{ABG}$ & & $\begin{array}{l}12 \\
\text { months }\end{array}$ & $82.22 \%$ \\
\hline $\begin{array}{l}\text { Thaler et al. } \\
(2013)^{41}\end{array}$ & $\begin{array}{l}\text { Radiograph: Bony bridging, bony continuity between endplate, trabecular } \\
\text { structure in anterior bone and lack of radiolucent lines } \\
\text { CT: } 30 \% \text { of endplate to endplate bridging anteriorly. Continuous intersegmental } \\
\text { bridging in posterior column. }\end{array}$ & $\beta$ - TCP (Chronos, Synthes) & $\begin{array}{l}\text { Smoking }-32.4 \% \\
\text { Previous lumbar } \\
\text { surgery adjacent to } \\
\text { index level }-23.5 \%\end{array}$ & $\begin{array}{l}12 \\
\text { months }\end{array}$ & $\begin{array}{l}\text { Radiographic } \\
-47.7 \% \\
\text { CT }-61.4 \%\end{array}$ \\
\hline \multirow{4}{*}{$\begin{array}{l}\text { Berjano,et } \\
\text { al. }(2015)^{35}\end{array}$} & \multirow{4}{*}{ CT: Evidence of bridging trabecular bone from lower endplate to upper endplate } & $\begin{array}{l}\text { Synthetic bone graft comprised of calcium phosphate granules and hydroxyapatite (Attrax, } \\
\text { Nuvasive) }\end{array}$ & Not available & $\begin{array}{l}12 \\
\text { months }\end{array}$ & $83 \%$ \\
\hline & & Nanocrystals -nanohydroxyapatite-based bone graft substitute (Nanostim, Medtronic) & Not available & $\begin{array}{l}12 \\
\text { months }\end{array}$ & $100 \%$ \\
\hline & & ABG & Not available & $\begin{array}{l}12 \\
\text { months }\end{array}$ & $75 \%$ \\
\hline & & Calcium triphosphate & Not available & $\begin{array}{l}12 \\
\text { months }\end{array}$ & $89 \%$ \\
\hline \multirow{2}{*}{$\begin{array}{l}\text { Kurd et al. } \\
(2014)^{18}\end{array}$} & \multirow{2}{*}{$\begin{array}{l}\text { CT: Brantigan, Steffee, Fraser method } 42 \\
\text { Radiographs: }<5 \text { degrees motion }\end{array}$} & $\begin{array}{l}\text { Osteconductive - allografts, tri-calcium phosphate (Vitoss, Orthovita, Inc), silicate-substituted } \\
\text { calcium phosphate (Actifuse, ApaTech), ceramics (Mastergraft, Medtronic), and } \\
\text { hydroxyapatite products (nannOss, Pioneer) }\end{array}$ & $\begin{array}{l}\text { BMI (mean, SD) - } \\
32.5,7.1 \\
\text { Smoking - } 39.2 \%\end{array}$ & $\begin{array}{l}12 \\
\text { months }\end{array}$ & $93.75 \%$ \\
\hline & & $\begin{array}{l}\text { Osteoinductive - rhBMP-2 (Infuse Kit, Medtronic), demineralized bone matrices (Grafton } \\
\text { DBM Matrix, Medtronic, Progenix DBM Putty, Medtronic), and stem cell-based products } \\
\text { (Osteocel Plus, Nuvasive Inc) }\end{array}$ & $\begin{array}{l}\text { BMI (mean, SD): } 30.6 \text {, } \\
6.4 \\
\text { Smoking (\%): } 36.1 \%\end{array}$ & $\begin{array}{l}12 \\
\text { months }\end{array}$ & $87.18 \%$ \\
\hline
\end{tabular}

*Not available for sale in the USA. 
Clinical Outcomes

Patient clinical outcomes indicated that one and twolevel BAS fusion patients improved from preoperative scores. Average ODI improvement was 18.5 and 14.7 for one and two-level patients respectively. VAS back pain for one and two-level patients improved 22.2 and 27.0 points. VAS leg pain improvement for right and left legs was 15.9 and 8.0 (one-level) and 14.0 and 19.1 (two-level). Literature is unclear on an accepted minimum clinically important difference (MCID) for patient outcomes. Carragee and Cheng ${ }^{43}$ reported the patient's pain should be reduced to $30 \mathrm{~mm}$ or less, with ODI improvement of at least 20 points to meet MCID. Copay et al. analyzed MCID and found that an ODI improvement of 12.8 was appropriate, while back pain needed to improve by $11.6 \mathrm{~mm}$ and leg pain $16.4 \mathrm{~mm} .{ }^{44}$ Malham et al., in an rhBMP-2 study reported improvement in ODI from 50.5 to 24.0 . VAS back was pain reduced from $64 \mathrm{~mm}$ to $26 \mathrm{~mm} .{ }^{26}$ Outcomes after allograft cellular bone matrix are reported as ODI improvement from 45.7 to 27.1, VAS back improved from 74 $\mathrm{mm}$ to $34 \mathrm{~mm}$, and VAS leg improved from $68 \mathrm{~mm}$ to $38 \mathrm{~mm}$. The BAS patient outcomes reported here meet some of the variable MCID requirements reported in the literature, but the improvements are not as large as other bone graft studies. However, the large number of comorbidities in these patients should be considered when reviewing the patient outcomes in comparison to prospective studies with restrictive inclusion/exclusion criteria. ${ }^{6,26}$

\section{Adverse Events}

No adverse events related to BAS were reported during this study. Although one patient required subsequent surgery to remove painful hardware, it was unrelated to bone graft material. The morbidities associated with ABG, such as blood loss, abnormal sensation, and long term pain at the donor site have been well documented. ${ }^{27,29,30}$ The complications with rhBMP-2 remain unclear and controversial, but include increased cancer risk, ectopic bone formation, and hematoma. ${ }^{45-48}$ The Osteocel Plus studies did not report any adverse events related to the graft material, but the number of patients in these studies were small. ${ }^{17,40}$ Given the small number of patients enrolled on this and other studies, adverse events should continue to be collected and reviewed on larg- er scale studies of bone graft substitutes.

\section{Limitations}

The largest limitation to this study was its retrospective nature. Clinical data is rarely available for all patients in a retrospective study and this study was no exception. The follow-up rate was reasonable for a retrospective study, but is not the same level as a prospective RCT. However, this retrospective study included a largely comorbid population allowing for a "real conditions of use" study of BAS in lumbar spinal fusion. Although this study has limitations, the high fusion rates and lack of any related adverse events in this population are promising. Further prospective studies should be conducted to investigate safety and efficacy of $\mathrm{NuCel}$ in a larger patient population.

\section{References}

1. Zdeblick TA. A prospective, randomized study of lumbar fusion. Preliminary results. Spine (Phila $\mathrm{Pa}$ 1976). 1993;18(8):983-91.

2. Banwart JC, Asher MA, Hassanein RS. Iliac crest bone graft harvest donor site morbidity. A statistical evaluation. Spine (Phila Pa 1976).

1995;20(9):1055-60.

3. Dimitriou R, Mataliotakis GI, Angoules AG, Kanakaris NK, Giannoudis PV. Complications following autologous bone graft harvesting from the iliac crest and using the RIA: a systematic review. Injury. 2011;42 Suppl 2:S3-15.

4. Park JJ, Hershman S, Kim YH. Updates in the Use of Bone Grafts in the Lumbar Spine. Bull Hosp Jt Dis. 2013;71:39-48.

5. Burkus JK, Gornet MF, Dickman CA, Zdeblick TA. Anterior lumbar interbody fusion using rhBMP-2 with tapered interbody cages. J Spinal Disord Tech. 2002;15(5):337-49.

6. Burkus JK, Transfeldt EE, Kitchel SH, Watkins RG, Balderston RA. Clinical and radiographic outcomes of anterior lumbar interbody fusion using recombinant human bone morphogenetic protein-2. Spine (Phila Pa 1976). 2002;27(21):2396-408.

7. Benglis D, Wang MY, Levi AD. A comprehensive review of the safety profile of bone morphogenetic protein in spine surgery. Neurosurgery. 2008;62(5 
Suppl 2):ONS423-31; discussion ONS31.

8. Mesfin A, Buchowski JM, Zebala LP, Bakhsh WR, Aronson AB, Fogelson JL, et al. High-dose rhBMP-2 for adults: major and minor complications: a study of 502 spine cases. J Bone Joint Surg Am. 2013;95(17):1546-53.

9. Shields LB, Raque GH, Glassman SD, Campbell M, Vitaz T, Harpring J, et al. Adverse effects associated with high-dose recombinant human bone morphogenetic protein-2 use in anterior cervical spine fusion. Spine (Phila Pa 1976). 2006;31(5):542-7. 10. Vines JB, Aliprantis AO, Gomoll AH, Farr J. Cryopreserved Amniotic Suspension for the Treatment of Knee Osteoarthritis. J Knee Surg. 2015. 11. Delo DM, De Coppi P, Bartsch G, Jr., Atala A. Amniotic fluid and placental stem cells. Methods Enzymol. 2006;419:426-38.

12. In 't Anker PS, Scherjon SA, Kleijburg-van der Keur C, Noort WA, Claas FH, Willemze R, et al. Amniotic fluid as a novel source of mesenchymal stem cells for therapeutic transplantation. Blood. 2003;102(4):1548-9.

13. Rodrigues MT, Lee SJ, Gomes ME, Reis RL, Atala A, Yoo JJ. Amniotic fluid-derived stem cells as a cell source for bone tissue engineering. Tissue Eng Part A. 2012;18(23-24):2518-27.

14. Faulk WP, Matthews R, Stevens PJ, Bennett JP, Burgos H, Hsi BL. Human amnion as an adjunct in wound healing. Lancet. 1980;1(8179):1156-8.

15. Karacal N, Kosucu P, Cobanglu U, Kutlu N. Effect of human amniotic fluid on bone healing. J Surg Res. 2005;129(2):283-7.

16. Kerimoglu S, Livaoglu M, Sonmez B, Yulug E, Aynaci O, Topbas M, et al. Effects of human amniotic fluid on fracture healing in rat tibia. J Surg Res. 2009;152(2):281-7.

17. Ammerman JM, Libricz J, Ammerman MD. The role of Osteocel Plus as a fusion substrate in minimally invasive instrumented transforaminal lumbar interbody fusion. Clin Neurol Neurosurg. 2013;115(7):991-4.

18. Kurd M, Cohick S, Park A, Ahmadinia K, Lee J, An H. Fusion in degenerative spondylolisthesis: comparison of osteoconductive and osteoinductive bone graft substitutes. Eur Spine J. 2014.

19. Sardar Z, Alexander D, Oxner W, Plessis S, Yee A, Wai EK, et al. Twelve-month results of a multi- center, blinded, pilot study of a novel peptide (B2A) in promoting lumbar spine fusion. J Neurosurg Spine. 2015;22(4):358-66.

20. McAfee PC, Boden SD, Brantigan JW, Fraser RD, Kuslich SD, Oxland TR, et al. Symposium: a critical discrepancy-a criteria of successful arthrodesis following interbody spinal fusions. Spine (Phila $\mathrm{Pa}$ 1976). 2001;26(3):320-34.

21. Pilitsis JG, Lucas DR, Rengachary SS. Bone healing and spinal fusion. Neurosurg Focus.

2002;13(6):e1.

22. Crawford CH, 3rd, Carreon LY, Djurasovic M, Glassman SD. Lumbar fusion outcomes in patients with rheumatoid arthritis. Eur Spine J.

2008;17(6):822-5.

23. Mooney V, McDermott KL, Song J. Effects of smoking and maturation on long-term maintenance of lumbar spinal fusion success. J Spinal Disord. 1999;12(5):380-5.

24. Andersen T, Christensen FB, Laursen M, Hoy $\mathrm{K}$, Hansen ES, Bunger C. Smoking as a predictor of negative outcome in lumbar spinal fusion. Spine (Phila Pa 1976). 2001;26(23):2623-8.

25. Snider RK, Krumwiede NK, Snider LJ, Jurist JM, Lew RA, Katz JN. Factors affecting lumbar spinal fusion. J Spinal Disord. 1999;12(2):107-14.

26. Malham GM, Parker RM, Ellis NJ, Blecher $\mathrm{CM}$, Chow FY, Claydon MH. Anterior lumbar interbody fusion using recombinant human bone morphogenetic protein-2: a prospective study of complications. J Neurosurg Spine. 2014;21(6):851-60.

27. Kalfas IH. Principles of bone healing. Neurosurg Focus. 2001;10(4):E1.

28. Sorensen KH. Anterior interbody lumbar spine fusion for incapacitating disc degeneration and spondylolisthesis. Acta Orthop Scand. 1978;49(3):269-77.

29. Chau AM, Mobbs RJ. Bone graft substitutes in anterior cervical discectomy and fusion. Eur Spine J. 2009;18(4):449-64.

30. Silber JS, Anderson DG, Daffner SD, Brislin BT, Leland JM, Hilibrand AS, et al. Donor site morbidity after anterior iliac crest bone harvest for single-level anterior cervical discectomy and fusion. Spine (Phila Pa 1976). 2003;28(2):134-9.

31. Santos ER, Goss DG, Morcom RK, Fraser RD. Radiologic assessment of interbody fusion using car- 
bon fiber cages. Spine (Phila Pa 1976).

2003;28(10):997-1001.

32. Dimar JR, Glassman SD, Burkus KJ, Carreon

LY. Clinical outcomes and fusion success at 2 years of single-level instrumented posterolateral fusions with recombinant human bone morphogenetic protein-2/compression resistant matrix versus iliac crest bone graft. Spine (Phila Pa 1976).

2006;31(22):2534-9; discussion 40.

33. Park DK, Kim SS, Thakur N, Boden SD. Use of recombinant human bone morphogenetic protein-2 with local bone graft instead of iliac crest bone graft in posterolateral lumbar spine arthrodesis. Spine (Phila Pa 1976). 2013;38(12):E738-47.

34. Lauweryns $P$, Raskin Y. Prospective analysis of a new bone graft in lumbar interbody fusion: results of a 2- year prospective clinical and radiological study. Int J Spine Surg. 2015;9.

35. Berjano P, Langella F, Damilano M, Pejrona M, Buric J, Ismael M, et al. Fusion rate following extreme lateral lumbar interbody fusion. Eur Spine J. 2015.

36. Nagineni VV, James AR, Alimi M, Hofstetter C, Shin BJ, Njoku I, Jr., et al. Silicate-substituted calcium phosphate ceramic bone graft replacement for spinal fusion procedures. Spine (Phila $\mathrm{Pa} 1976$ ).

2012;37(20):E1264-72.

37. Jenis LG, Banco RJ. Efficacy of silicatesubstituted calcium phosphate ceramic in posterolateral instrumented lumbar fusion. Spine (Phila $\mathrm{Pa}$ 1976). 2010;35(20):E1058-63.

38. Nandyala SV, Marquez-Lara A, Fineberg SJ, Pelton M, Singh K. Prospective, randomized, controlled trial of silicate-substituted calcium phosphate versus rhBMP-2 in a minimally invasive transforaminal lumbar interbody fusion. Spine (Phila $\mathrm{Pa}$ 1976). 2014;39(3):185-91.

39. Roh JS, Yeung CA, Field JS, McClellan RT. Allogeneic morphogenetic protein vs. recombinant human bone morphogenetic protein-2 in lumbar interbody fusion procedures: a radiographic and economic analysis. J Orthop Surg Res. 2013;8:49.

40. Tohmeh AG, Watson B, Tohmeh M, Zielinski $\mathrm{XJ}$. Allograft cellular bone matrix in extreme lateral interbody fusion: preliminary radiographic and clinical outcomes. ScientificWorldJournal.

2012;2012:263637.
41. Thaler M, Lechner R, Gstottner M, Kobel C, Bach $\mathrm{C}$. The use of beta-tricalcium phosphate and bone marrow aspirate as a bone graft substitute in posterior lumbar interbody fusion. Eur Spine J. 2013;22(5):1173-82.

42. Fogel GR, Toohey JS, Neidre A, Brantigan JW. Fusion assessment of posterior lumbar interbody fusion using radiolucent cages: $\mathrm{X}$-ray films and helical computed tomography scans compared with surgical exploration of fusion. Spine J. 2008;8(4):570-7.

43. Carragee EJ, Cheng I. Minimum acceptable outcomes after lumbar spinal fusion. Spine J.

2010;10(4):313-20.

44. Copay AG, Glassman SD, Subach BR, Berven S, Schuler TC, Carreon LY. Minimum clinically important difference in lumbar spine surgery patients: a choice of methods using the Oswestry Disability Index, Medical Outcomes Study questionnaire Short Form 36, and pain scales. Spine J. 2008;8(6):968-74. 45. Vavken J, Mameghani A, Vavken P, Schaeren S. Complications and cancer rates in spine fusion with recombinant human bone morphogenetic protein-2 (rhBMP-2). Eur Spine J. 2015.

46. Cahill KS, McCormick PC, Levi AD. A comprehensive assessment of the risk of bone morphogenetic protein use in spinal fusion surgery and postoperative cancer diagnosis. J Neurosurg Spine.

2015:1-8.

47. Fu R, Selph S, McDonagh M, Peterson K, Tiwari A, Chou R, et al. Effectiveness and harms of recombinant human bone morphogenetic protein-2 in spine fusion: a systematic review and meta-analysis. Ann Intern Med. 2013;158(12):890-902.

48. Simmonds MC, Brown JV, Heirs MK, Higgins JP, Mannion RJ, Rodgers MA, et al. Safety and effectiveness of recombinant human bone morphogenetic protein-2 for spinal fusion: a meta-analysis of individual-participant data. Ann Intern Med. 2013;158(12):877-89.

\section{Disclosures \& COI}

Pierce Nunley, MD is a consultant for Nutech Medical, and received clinical and research support from Nutech Medical. Eubulus J. Kerr III, MD, Philip A. Utter, MD, David A. Cavanaugh, MD, Kelly A. Frank, MS, Devan Moody, Brian McManus, and Marcus B. Stone, $\mathrm{PhD}$ received clinical and re- 
search support from Nutech.

\section{Corresponding Author}

Pierce D. Nunley, MD, Spine Institute of Louisiana 1500 Line Avenue Suite 200, Shreveport, LA 71101. pnunley@louisianaspine.org.
Published 18 April 2016.

This manuscript is generously published free of charge by ISASS, the International Society for the Advancement of Spine Surgery. Copyright $\odot 2016$ ISASS. To see more or order reprints or permissions, see http://ijssurgery.com. 